\section{JURNAL}

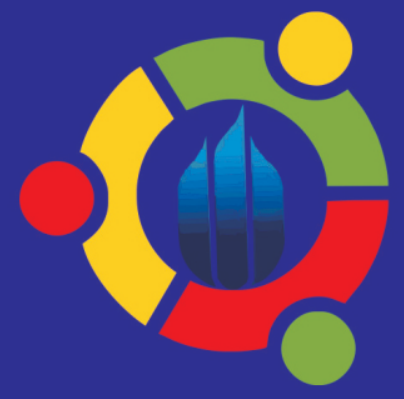

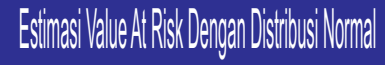

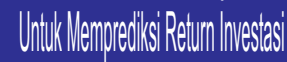

Hememenat

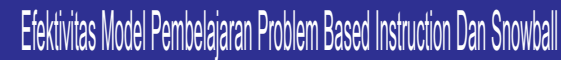

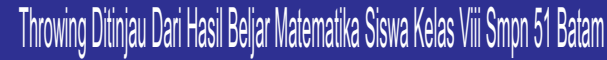

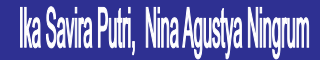

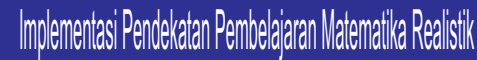

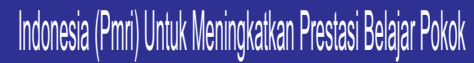

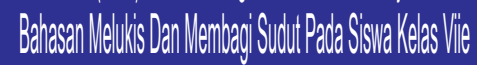
Smplogenil Seilegan

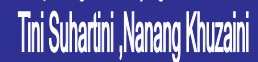

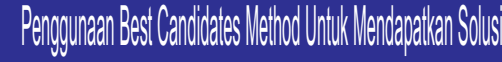

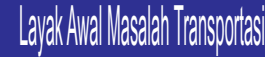

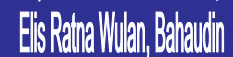

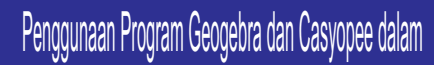

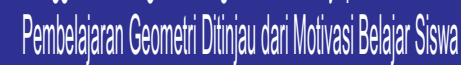

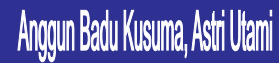

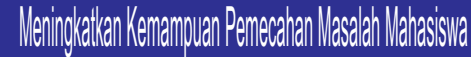

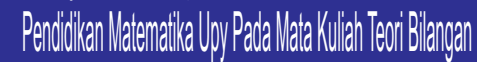

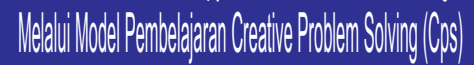
sistecanteningsin

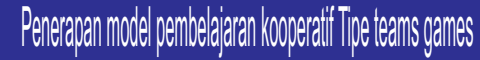

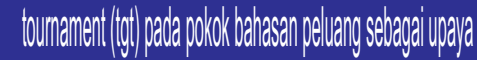

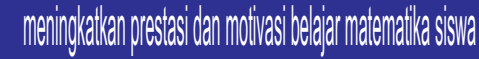

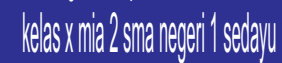
Numeaniciaten

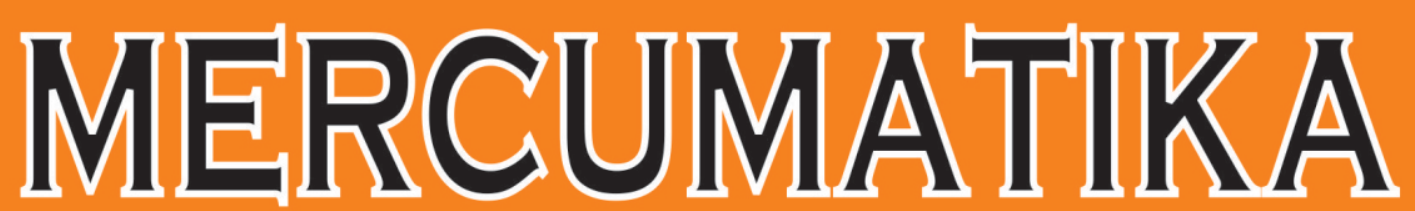

Jurnal Penelitian Matematika dan Pendidikan Matematika

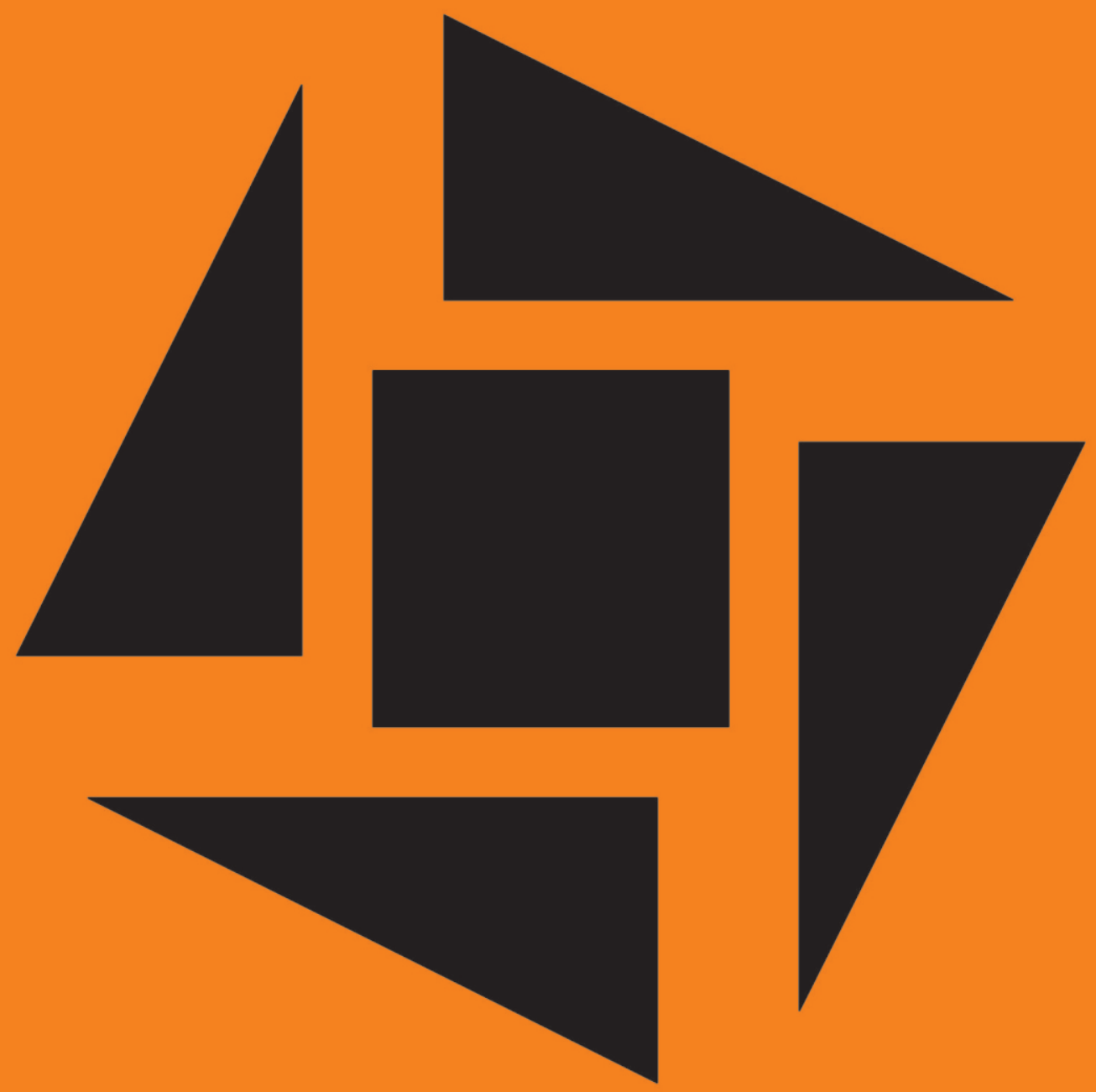

PROGRAM STUDI PENDIDIKAN MATEMATIKA FAKULTAS KEGURUAN dan ILMU PENDIDIKAN UNIVERSITAS MERCU BUANA YOGYAKARTA 


\title{
PEMIMPIN REDAKSI
}

Heru Sukoco, S.Si., M.Pd

SEKRETARIS REDAKSI

Isna Khalifa, M.Sc

Muhammad Irfan Rumasoreng, M.Pd

DEWAN REDAKSI

Prof. Dr. Rusgianto H.S., M.Pd (Universitas Negeri Yogyakarta)

Dr. Sugiman (Universitas Negeri Yogyakarta)

Dr. Ibrahim, M.Pd (Universitas Sunan Kalijaga Yogyakarta)

Nuryadi, S.Pd.Si., M.Pd

\author{
ADMINISTRASI DAN SIRKULASI \\ Tri Andi, S.T \\ ALAMAT REDAKSI \\ Universitas Mercu Buana Yogyakarta \\ Jalan Wates km. 10 \\ Yogyakarta 55753 \\ Telpon (0274) 6498212 pesawat 145 \\ Fax (0274) 6498213 \\ http://ejurnal.mercubuana-yogya.ac.id \\ Email: jurnal.umby@gmail.com
}

Jurnal Mercumatika (JM) diterbitkan oleh Unit Publikasi Ilmiah \& HaKI

Universitas Mercu Buana Yogyakarta, Merupakan wahana bagi dosen, mahasiswa, guru, dan juga praktisi pendidikan untuk menampilkan karya ilmiahnya, baik berupa hasil penelitian maupun kajian artikel hasil penelitian bidang pendidikan matematika dan matematika.

JM terbit dua kali setahun.

Redaksi menerima naskah yang belum pernah dipublikasikan. Pedoman penulisan naskah untuk JM tercantum pada bagian akhir jurnal ini.

Surat-menyurat mengenai artikel yang akan diterbitkan, langganan, keagenan dll, dialamatkan langsung ke alamat redaksi. 


\section{DAFTAR ISI}

Dewan Redaksi.

i

Kata Pengantar.

Daftar Isi

Estimasi Value At Risk Dengan Distribusi Normal Untuk Memprediksi Return Investasi

Hermansah.

Efektivitas Model Pembelajaran Problem Based Instruction Dan Snowball Throwing Ditinjau Dari Hasil Beljar Matematika Siswa Kelas Viii Smpn 51 Batam

Ika Savira Putri, Nina Agustya Ningrum.

Implementasi Pendekatan Pembelajaran Matematika Realistik Indonesia (Pmri) Untuk Meningkatkan Prestasi Belajar Pokok Bahasan Melukis Dan Membagi Sudut Pada Siswa Kelas Viie Smp Negeri I Seyegan

Tini Suhartini ,Nanang Khuzaini.

Penggunaan Best Candidates Method Untuk Mendapatkan Solusi Layak Awal Masalah Transportasi

Elis Ratna Wulan, Bahaudin

Penggunaan Program Geogebra dan Casyopee dalam Pembelajaran Geometri Ditinjau dari Motivasi Belajar Siswa

Anggun Badu Kusuma, Astri Utami

Meningkatkan Kemampuan Pemecahan Masalah Mahasiswa Pendidikan Matematika Upy Pada Mata Kuliah Teori Bilangan Melalui Model Pembelajaran Creative Problem Solving (Cps)

siska candra ningsih.

Penerapan model pembelajaran kooperatif Tipe teams games tournament (tgt) pada pokok bahasan peluang sebagai upaya meningkatkan prestasi dan motivasi belajar matematika siswa kelas $x$ mia 2 sma negeri 1 sedayu

Nurmahmidah. 


\title{
Penggunaan Best Candidates Method Untuk Mendapatkan Solusi Layak Awal Masalah Transportasi
}

\author{
Elis Ratna Wulan', , Bahaudin ${ }^{2}$ \\ Jurusan Matematika Fakultas Sains dan Teknologi \\ Universitas Islam Negeri Sunan Gunung Djati Bandung \\ 1'elis_ratna_wulan@uinsgd.ac.id, 2baha23@ymail.com
}

\begin{abstract}
Abstrak
Besarnya ongkos transportasi dapat menurunkan maksimasi profit sehingga biaya distribusi perlu ditekan. Salah satu cara untuk menekan biaya transportasi tersebut adalah dengan menggunakan model masalah transportasi dengan mencari solusi layak awal. Salah satu metode untuk mencari solusi layak awal adalah dengan Best Candidates Method (BCM). Pada BCM, kandidat dipilih dengan memilih dua unit ongkos terkecil untuk tiap-tiap baris, kemudian kandidat-kandidat tersebut disusun sehingga membentuk kombinasi-kombinasi yang menghasilkan total biaya terkecil. Best Candidate Method menghasilkan solusi layak awal dengan total ongkos terkecil dengan cara membandingkan total ongkos antara kombinasi yang satu dengan kombinasi lainnya. Pada contoh kasus yang dipelajari, contoh kasus pertama yaitu distribusi pupuk berbentuk model masalah transportasi tidak seimbang dengan total supply sebesar 51 ton pupuk dan demand sebesar 52 ton pupuk. Hasil akhir yang diperoleh yaitu solusi layak awal dengan total cost terkecil adalah $\$ 1005$. Sedangkan contoh kasus kedua yaitu distribusi air minum berbentuk masalah transportasi seimbang dengan total supply sama dengan total demand yaitu sebesar 12 kilo liter dengan hasil akhir yang diperoleh yaitu solusi layak awal dengan total cost terkecil adalah sebesar \$23.
\end{abstract}

Kata kunci : Best Candidates Method, Solusi Layak Awal, Masalah Transportasi, Model Masalah Transportasi tidak Seimbang, Model Masalah Transportasi Seimbang.

\section{The Use Of The Best Candidates Method To Get Solution Worthy Of Early Transportation Problems}

\begin{abstract}
The magnitude of the cost of transportation can reduce maksimasi profit so the cost of distribution need to be pressed. One way to reduce the cost of transportation is by using the model of transportation problem with finding a viable solution to the beginning. One method to find the solution worthy of the beginning is with Best Candidates Method (BCM). At a BCM, the candidate chosen by selecting the two units the smallest cost for each line, and then the candidates are arranged so as to form a combination-a combination that produces the smallest total cost. Best Candidate Method produces viable solution beginning with the smallest total postage by means of comparing the total cost between the combinations with other combinations. In case the first case study, namely the distribution of fertilizer-shaped model of transportation problem was disproportionate to the total supply amounted to 51 tons of fertilizer and demand of 52 tons of fertilizer. The end result is obtained that is a solution worth beginning with the smallest total cost is $\$ 1005$. While the second case i.e. the distribution of drinking water-shaped transportation problems in balance with the total supply equals total demand namely of 12 kilo liters with the end result is obtained that is a solution worth beginning with the smallest total cost is $\$ 23$.
\end{abstract}

Keywords: Best Candidates Worthy Solution Method, Early, problems of transport, Transport Problems not balanced Model, a Model of Balanced Transport Problems. 


\section{Pendahuluan}

Model transportasi merupakan bagian dari Linear Programing di mana fungsi tujuan dari model transportasi adalah minimasi yang artinya untuk mendapatkan total biaya minimum. Dalam penyelesaian model transportasi hal yang perlu dilakukan adalah menentukan solusi layak awal. Ada banyak metode dalam menentukan solusi layak awal, salah satu diantaranya adalah Best Candidates Method (BCM). Metode ini menggunakan dua biaya terkecil pada tiap baris sebagai candidates. Setelah menentukan kandidatkandidatnya, kandidat-kandidat tersebut dipasang-pasangkan sehingga membentuk kombinasi-kombinasi. Metode Best Candidates Method merupakan metode solusi layak awal yang belum banyak dikenal dan digunakan untuk penyelesaian masalah transportasi.

\section{Teori}

Model transportasi adalah kelas khusus dari pemrograman linear yang berhubungan dengan pengiriman komoditas dari sources (misalnya pabrik) ke destination (misalnya gudang), bertujuan untuk menentukan jadwal pengiriman yang meminimumkan jumlah biaya pengiriman, sementara supply dan demand terpenuhi [1]. Model Transportasi juga didefinisikan sebagai suatu metode yang digunakan untuk mengatur distribusi suatu produk dari sumber yang menyediakan ke tempat tujuan secara optimal dengan tujuan menentukan jumlah produk yang harus dikirim dari sumber ke tempat tujuan dengan sejumlah biaya yang minimum [2]. Dalam bentuk jaringan, model transportasi dapat dideskripsikan: tempat asal atau sumber (misalnya $m$ ) dihubungkan ke tempat tujuan (misalnya $n$ ), sumber dan tujuan direpresentasikan dengan node dan rute pengiriman komoditi direpresentasikan dengan busur atau $\operatorname{arc}$ seperti yang terlihat pada gambar 1. Dari Gambar 1 ai adalah supply atau persediaan pada source atau sumber sedangkan bj adalah demand atau permintaan pada destination atau tujuan. $m$ adalah banyaknya source dan $\mathrm{n}$ adalah banyaknya destination. $\mathrm{xij}$ adalah jumlah unit yang dikirim dari sumber ke tujuan dan $\quad c_{i j}$ adalah besarnya ongkos pengiriman per unit dari sumber ke tujuan. Sedangkan formulasi dari model masalah transportasi adalah besarnya ongkos pengiriman per unit dari sumber ke tujuan. Sedangkan formulasi dari model masalah transportasi adalah

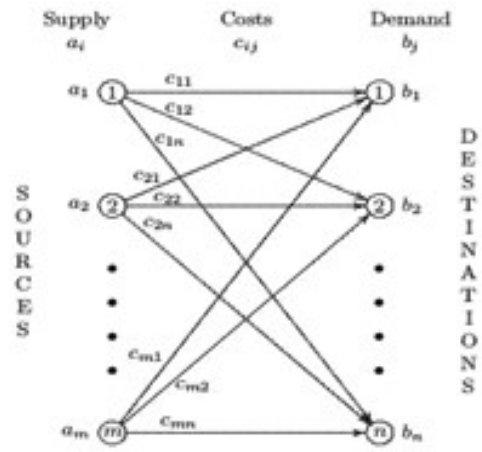

Gambar 1 Representasi model transportasi dalam bentuk jaringan [3]

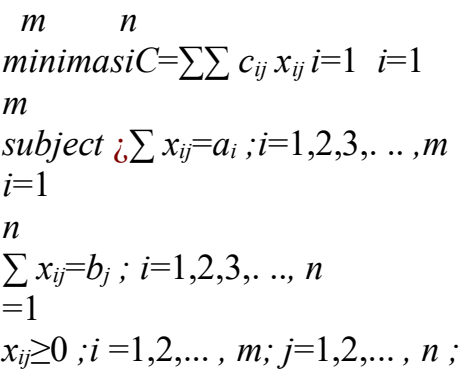

Berdasarkan banyaknya supply dan demand, masalah transportasi terbagi menjadi masalah transportasi

\begin{tabular}{|c|c|}
\hline eimbang yaitu suatu kondisi di mana & $\sum_{i=1} a_{i}=\sum b_{j}$ \\
\hline
\end{tabular}

transportasi tidak seimbang yaitu suatu kondisi

di mana $\sum_{i=1} a_{i}>\sum_{j=1} b_{j}$ atau $\quad \sum_{i=1} a_{i}<\sum b_{j}$

Pada masalah transportasi tidak seimbang perlu digunakan, baris dummy atau kolom dummy untuk menyeimbangkan antara supply dan demand.

Secara umum, algoritma transportasi memenuhi langkah-langkah berikut, menurut Siswanto ada lima langkah algoritma transportasi sebagai berikut [4],

1. Diagnosis masalah dimulai dengan pengenalan sumber,tujuan, parameter dan 
variabel.

2. Seluruh informasi tersebut dituangkan ke dalam matriks transportasi, yaitu jika kapasitas seluruh sumber lebih besar dari permintaan seluruh tujuan maka sebuah kolom semu perlu ditambahkan untuk menampung kelebihan kapasitas tersebut. Namun, bila kapasitas seluruh sumber lebih kecil dari seluruh permintaan tujuan maka sebuah baris semu perlu ditambahkan.

3. Setelah matriks transportasi terbentuk, mulailah menyusun tabel awal. Ada beberapa metode untuk menyusun tabel awal diantaranya yaitu North West Corner Method, dan Vogel Aproximation Method. Metode-metode tersebut berfungsi untuk menentukan alokasi distribusi awal yang akan membuat seluruh kapasitas sumber teralokasikan ke seluruh tujuan.

4. Menguji optimalitas tabel untuk mengetahui apakah biaya distribusi total telah minimum. model pengujian optimalitas algoritma transportasi, misalnya stepping stone method dan modified distribution method.

5. Revisi tabel bila langkah keempat terbukti belum optimal.

Solusi layak awal dihasilkan dari metodemetode solusi layak awal, di mana sel basis pada tabel transportasi jumlahnya $m+n-1$. pada paper ini, ditunjukkan bagaimana BCM mendapatkan solusi layak awal.

Adapun langkah-langkah best candidates method sebagai berikut [5].

Langkah pertama, periksa keseimbangan matriks, Jika total supply sama dengan total demand, maka matriks dikatakan seimbang dan dilanjutkan ke Langkah 2. Jika total supply tidak sama dengan total demand, maka kita menambahkan baris dummy atau kolom dummy yang diperlukan untuk membuat supply sama dengan demand. Kemudian biaya transportasi pada baris dummy atau kolom dummy tersebut diisi dengan nol. Unit cost pada baris dummy atau kolom dummy tidak dipilih sebagai kandidat.

Langkah kedua, pilih dua kandidat di tiaptiap baris, jika terdapat kandidat yang bernilai sama lebih dari satu, maka pilih kandidat tersebut. Setelah itu periksa kolom, jika kolom tidak terdapat kandidat maka pilih kandidat yang sudah tersedia.

Langkah ketiga, identifikasi baris dengan kandidat biaya terkecil dari kombinasi terpilih. Kemudian alokasikan demand dan supply sebanyak mungkin ke variabel dengan unit biaya terkecil dalam baris atau kolom yang dipilih. kemudian sesuaikan penawaran dan permintaan dengan mencoret baris atau kolom kemudian diganti dengan nilai nol. Jika baris atau kolom tidak menjadi nol, maka alokasikan ke unit biaya terkecil selanjutnya pada baris atau kolom tersebut.

Langkah keempat, pilih kandidat biaya terkecil berikutnya dari kombinasi terpilih dan ulangi langkah 3 sampai semua kolom dan baris habis.

\section{Hasil dan Diskusi}

Pada bagian ini akan ditunjukkan penyelesaian kasus dengan tahapan-tahapan BCM dalam mendapatkan solusi layak awal. Contoh kasus pertama akan dibahas model transportasi tidak seimbang. Sedangkan pada contoh kasus dua dibahas masalah transportasi seimbang. Sebelum contoh kasus dibahas hal yang perlu dilakukan adalah membuat tabel transportasi,

Tabel 1. Tabel model transportasi [5]

\begin{tabular}{|l|l|l|l|l|}
\hline $\begin{array}{l}\text { Origins } \\
\text { (Factories) }\end{array}$ & $\begin{array}{l}\text { Destinations } \\
\text { (Warehouses) }\end{array}$ & Available \\
\hline & $12 \ldots \ldots \ldots n$ & & \\
\hline 1 & $c_{I I}$ & $c_{I 2}$ & $c_{l n}$ & $a_{I}$ \\
\hline 2 & $c_{2 I}$ & $c_{22}$ & $c_{2 n}$ & $a_{2}$ \\
\hline$\ldots$ & $\ldots$ & $\ldots$ & $\ldots$ & $\ldots$ \\
\hline $\mathrm{m}$ & $c_{m I}$ & $c_{m 2}$ & $c_{m !}$ & $a_{m}$ \\
\hline Required & $b_{I}$ & $b_{2}$ & $b_{n}$ & \\
\hline
\end{tabular}

\section{Contoh kasus pertama}

Suatu perusahaan pupuk memiliki empat pabrik di beberapa kota. Misalkan pabrik pertama berada di kota S1, pabrik kedua berada di kota S2, pabrik ketiga berada di kota S3 dan pabrik keempat berada di kota S4. Produksi pupuk dari keempat pabik tersebut akan dikirim ke kota tujuan D1, D2, D3 dan D4. Pihak manajemen mengatur pola distribusi dengan mengalokasikan sejumlah persediaan berdasarkan pada beban biaya transportasi, dan 
jika terdapat salah satu pabrik dari keempat pabrik tersebut tidak mampu memenuhi permintaan suatu kota tujuan maka persediaan akan dikirim dari pabrik lain, tentunya berdasarkan besarnya ongkos transportasi. Produksi barang dari keempat pabrik tersebut jika dijumlahkan sebesar 51 Ton dan permintaan masing-masing kota jika dijumlahkan semuanya sebesar 52 Ton. Biaya transportasi masing-masing pabrik ke semua tempat tujuan dapat dilihat dari Tabel 2 dengan satuan biaya dalam dolar (\$). Karena jumlah persediaan dan permintaan tidak sesuai maka model transportasi yang terbentuk berupa model transportasi tidak seimbang. Untuk lebih jelasnya dapat dilihat pada Tabel 2 ,

Tabel 2. Model transportasi tidak seimbang [5]

\begin{tabular}{|l|r|r|r|r|r|r|}
\hline Plant & D1 & D2 & D3 & D4 & \multicolumn{1}{|l|}{ Supply } \\
\hline S1 & 10 & 30 & 25 & 15 & 14 \\
\hline S2 & 20 & 15 & 20 & 10 & 10 \\
\hline S3 & 10 & 30 & 20 & 20 & 15 \\
\hline S4 & 30 & 40 & 35 & 45 & 12 \\
\hline Demand & \multirow{2}{*nnnyyy}{} & 10 & \multirow{2}{*}{15} & \multirow{2}{*}{12} & \multirow{2}{*}{15} & 51 \\
\cline { 6 - 7 } & & & & & & \\
\hline
\end{tabular}

Langkah pertama, total persediaan dengan total permintaan pada Tabel 2. harus diseimbangkan terlebih dahulu dengan menambahkan baris dummy, sehingga total persediaan sama dengan total permintaan

$$
\begin{aligned}
& n \quad m \\
& \sum_{\mathrm{i}} a_{i}=\sum b_{i}=52 \quad \text { (Lihat tabel 3) }
\end{aligned}
$$

Tabel 3. Model transportasi yang telah diseimbangkan

\begin{tabular}{|l|r|r|r|r|r|}
\hline Plant & D1 & D2 & D3 & D4 & \multicolumn{1}{l|}{ Supply } \\
\hline S1 & 10 & 30 & 25 & 15 & 14 \\
\hline S2 & 20 & 15 & 20 & 10 & 10 \\
\hline S3 & 10 & 30 & 20 & 20 & 15 \\
\hline S4 & 30 & 40 & 35 & 45 & 12 \\
\hline S5 & 0 & 0 & 0 & 0 & 1 \\
\hline Demand & \multirow{2}{*}{10} & \multirow{2}{*}{15} & \multirow{2}{*}{12} & \multirow{2}{*}{15} & 52 \\
\cline { 6 - 7 } & & & & & \\
\hline
\end{tabular}

Langkah kedua, memilih kandidat dengan masing-masing baris dipilih dua kandidat, perhatikan Tabel 3.3. Pada kolom D2 hanya terdapat satu kandidat karena unit ongkos terkecil selanjutnya yang ada pada kolom tersebut tidak bisa dipilih karena terletak pada baris yang telah memiliki dua kandidat. Hal serupa juga terjadi pada kolom D3 dimana $(\mathrm{D} 3, \mathrm{~S} 4)$ dipilih karena unit ongkos yang lain pada kolom tersebut tidak memungkinkan untuk dipilih. menunjukkan kandidat dengan dua unit ongkos terkecil di tiap-tiap baris.

Tabel 4 menentukan kandidat

\begin{tabular}{|l|r|r|r|r|r|r|}
\hline Plant & D1 & D2 & D3 & D4 & \multicolumn{2}{|l|}{ Supply } \\
\hline S1 & 10 & 30 & 25 & 15 & 14 \\
\hline S2 & 20 & 15 & 20 & 10 & 10 \\
\hline S3 & 10 & 30 & 20 & 20 & 15 \\
\hline S4 & 30 & 40 & 35 & 45 & 12 \\
\hline S5 & 0 & 0 & 0 & 0 & 1 \\
\hline \multirow{2}{*}{ Demand } & \multirow{2}{*}{10} & \multirow{2}{*}{15} & \multirow{2}{*}{12} & \multirow{2}{*}{15} & 52 \\
\cline { 5 - 7 } & & & & & &
\end{tabular}

Setelah menentukan kandidat kemudian pasangkan antara kandidat tersebut sehingga membentuk kombinasi. Selanjutnya masingmasing kombinasi berlaku langkah ketiga.. Terlihat dari Tabel 5 adalah kombinasi pertama dari model transportasi tidak seimbang dan Tabel 6 adalah kombinasi kedua model transportasi tidak seimbang. Tabel 5. Kombinasi pertama dari masalah transportasi tidak seimbang

Tabel 5. Kombinasi pertama dari masalah

\begin{tabular}{|c|c|c|c|c|c|}
\hline Plant & D1 & D2 & D3 & D4 & Supply \\
\hline S1 & & 30 & 25 & 15 & 14 \\
\hline $\mathrm{S} 2$ & 20 & 15 & 20 & 10 & 10 \\
\hline S3 & 10 & 30 & 20 & 20 & 15 \\
\hline S4 & 30 & 40 & 35 & 45 & 12 \\
\hline S5 & 0 & 0 & 0 & 0 & 1 \\
\hline \multirow{2}{*}{ Demand } & \multirow{2}{*}{10} & \multirow{2}{*}{15} & \multirow{2}{*}{12} & \multirow{2}{*}{15} & 52 \\
\hline & & & & & 52 \\
\hline
\end{tabular}
transportasi tidak seimbang

Tabel 6. Kombinasi kedua dari masalah

\begin{tabular}{|c|c|c|c|c|c|}
\hline Plant & D1 & D2 & D3 & D4 & Supply \\
\hline S1 & 10 & 30 & 25 & 15 & 14 \\
\hline $\mathrm{S2}$ & 20 & 15 & 20 & 10 & 10 \\
\hline $\mathrm{S3}$ & 10 & 30 & 20 & 20 & 15 \\
\hline$\$ 4$ & 30 & 40 & 35 & 45 & 12 \\
\hline S5 & 0 & 0 & 0 & 0 & 1 \\
\hline \multirow{2}{*}{ Demand } & \multirow{2}{*}{10} & \multirow{2}{*}{15} & \multirow{2}{*}{12} & \multirow{2}{*}{15} & 52 \\
\hline & & & & & 52 \\
\hline
\end{tabular}
transportasi tidak seimbang

Langkah ketiga, identifikasi baris-baris dengan nilai kandidat terkecil. setelah itu 
alokasikan persediaan dan permintaan sebesarbesarnya pada kandidat tersebut, jika masih menyisakan nilai persediaan atau permintaan, alokasikan nilai persediaan atau permintaan tersebut ke unit ongkos terkecil selanjutnya pada baris yang terpilih.

Tabel 7. Pengalokasian dimulai dari kandidat terkecil

\begin{tabular}{|c|c|c|c|c|c|}
\hline Plant & D1 & D2 & D3 & D4 & Supply \\
\hline S1 & 10 & 30 & 25 & 15 & 14 \\
\hline S2 & 20 & 15 & 20 & 10 & 10 \\
\hline S3 & 10 & 30 & 20 & 20 & 0 \\
\hline S4 & 30 & 40 & 35 & 45 & 12 \\
\hline S5 & 0 & 0 & 0 & 0 & 1 \\
\hline \multirow{2}{*}{ Demand } & \multirow{2}{*}{0} & \multirow{2}{*}{15} & \multirow{2}{*}{7} & \multirow{2}{*}{15} & 52 \\
\hline & & & & & 52 \\
\hline
\end{tabular}

Langkah keempat, ulangi langkah ketiga sampai semua nilai pesediaan atau permintaan menjadi nol. Perhatikan Tabel 8 dan Tabel 9.

Tabel 8. Pengalokasian supply dan demand sampai menjadi nol pada kombinasi pertama

\begin{tabular}{|c|c|c|c|c|c|c|c|c|}
\hline Plant & D1 & $D$ & & $\mathrm{D}^{3}$ & & & 24 & Supply \\
\hline S1 & 10 & & 30 & & 25 & 4 & 15 & 0 \\
\hline S2 & 20 & 10 & 15 & & 20 & & 10 & 0 \\
\hline S3 & 10 & 5 & 30 & & 20 & 1 & 20 & 0 \\
\hline S4 & 30 & & 40 & 12 & 35 & & 45 & 0 \\
\hline S5 & 0 & & 0 & & 0 & 1 & 0 & 0 \\
\hline \multirow{2}{*}{ Demand } & \multirow{2}{*}{0} & \multirow{2}{*}{\multicolumn{2}{|c|}{0}} & \multirow{2}{*}{\multicolumn{2}{|c|}{0}} & \multirow{2}{*}{\multicolumn{2}{|c|}{0}} & 52 \\
\hline & & & & & & & & 52 \\
\hline
\end{tabular}

diperoleh hasil pada kombinasi pertama masalah transportasi tidak seimbang yaitu, $10 * 10+10 * 15+5 * 30+12 * 35+4 * 15+10 * 20+1 *$ $0=1080$

Tabel 9. Pengalokasian supply dan demand sampai menjadi nol pada kombinasi kedua

\begin{tabular}{|c|c|c|c|c|c|c|c|c|}
\hline Plant & D1 & & $\mathrm{D} 2$ & $D 3$ & & D4 & & Supply \\
\hline S1 & & 10 & 30 & & 25 & 14 & 15 & \\
\hline $\mathrm{S} 2$ & & 201 & 15 & & 20 & & 10 & 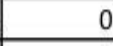 \\
\hline S3 & 10 & 10 & & 5 & 20 & & 20 & \\
\hline S4 & & 305 & 40 & 7 & 35 & & 45 & 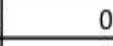 \\
\hline$\$ 5$ & & 0 & 0 & & 0 & 1 & 0 & 0 \\
\hline \multirow[t]{2}{*}{ Demand } & \multirow{2}{*}{\multicolumn{2}{|c|}{0}} & \multirow[t]{2}{*}{0} & \multirow{2}{*}{\multicolumn{3}{|c|}{0}} & \multirow[t]{2}{*}{0} & 52 \\
\hline & & & & & & & & 52 \\
\hline
\end{tabular}

diperoleh hasil pada kombinasi kedua masalah transportasi tidak seimbang yaitu, $10 * 10+10 * 15+5 * 40+5 * 20+7 * 35+14 * 15+1 * 0$ $=1005$

Pada contoh kasus pertama didapat dua kombinasi, dengan kombinasi pertama menghasilkan solusi layak awal atau biaya transportasi total sebesar $\$ 1080$ dan sel-sel yang teralokasi (S1,D1), (S1,D4), (S2,D2), (S3,D2), (S3,D4), (S4,D3) dan (S5,D4). Sedangkan kombinasi kedua masalah transportasi tidak seimbang menghasilkan solusi layak awal atau biaya transportasi total sebesar \$1005 dengan sel-sel yang teralokasi (S1,D4), (S2,D2), (S3,D1), (S3,D3), (S4,D2), (S4,D3) dan (S5,D4). Dengan membandingkan hasil solusi layak awal dari kedua kombinasi masalah transportasi tidak seimbang diatas dapat dilihat bahwa biaya transportasi akan minimum jika alokasi permintaan dan persediaan mengikuti alokasi kombinasi kedua masalah transportasi contoh kasus pertama.

\section{Contoh kasus kedua}

Suatu perusahaan air minum memiliki tiga sumber mata air di sejumlah lokasi yang berbeda dengan empat tujuan kota pendistribusian. Jika permintaan dari suatu kota tidak terpenuhi oleh salah satu tempat produksi air minum maka permintaan dari kota tersebut akan dipenuhi oleh tempat produksi air minum dari salah satu tiga lokasi tersebut. Lokasi sumber mata air tersebut masing-masing diberi label S1,S2 dan S3, kemudian empat kota tujuan diberi label D1, D2, D3, dan D4 dengan biaya transportasi dapat dilihat dari Tabel 10 (dalam \$). Total permintaan dan total persediaan masing-masing 12 kilo Liter sehingga model transportasi tersebut berbentuk model transportasi seimbang. Lebih jelasnya lihat Tabel 10,

Tabel 10. Masalah transportasi seimbang [3]

\begin{tabular}{|l|r|r|r|r|r|}
\hline Plant & D1 & D2 & D3 & D4 & \multicolumn{2}{|c|}{ Supply } \\
\hline S1 & 7 & 2 & 5 & 4 & 3 \\
\hline S2 & 3 & 5 & 4 & 1 & 4 \\
\hline S3 & 2 & 1 & 3 & 4 & 5 \\
\hline Demand & 3 & 4 & 2 & 3 & 12 \\
\hline
\end{tabular}

Pada contoh kasus kedua total supply dan total demand bernilai sama, sehingga langkahlangkah kedua, ketiga, dan keempat pada contoh kasus kedua pengerjaannya sama seperti langkah kedua, ketiga dan keempat pada contoh kasus pertama. Sehingga dapat diperoleh hasil perhitungan seperti terlihat pada tabel berikut,

Tabel 11. Alokasi biaya pada kombinasi pertama contoh kasus kedua 


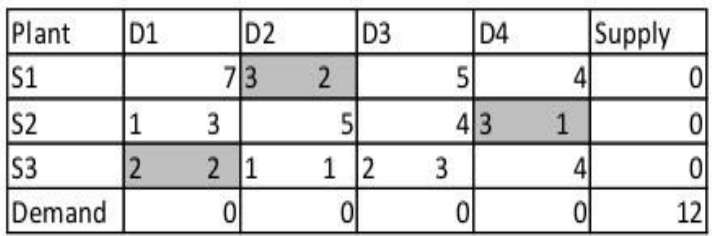

diperoleh hasil pada kombinasi kedua masalah transportasi tidak seimbang yaitu, $1 * 3+2 * 2+3 * 2+1 * 1+2 * 3+3 * 1+=23$

Tabel 12. Alokasi biaya pada kombinasi kedua contoh kasus kedua

\begin{tabular}{|l|rr|rr|ll|ll|r|}
\hline Plant & D1 & & D2 & D3 & D4 & Supply \\
\hline S1 & & 7 & & 2 & 2 & 5 & 1 & 4 & 0 \\
\hline S2 & 2 & 3 & & 5 & & 4 & 2 & 1 & 0 \\
\hline S3 & 1 & 2 & 4 & 1 & & 3 & & 4 & 0 \\
\hline Demand & & 0 & & 0 & & 0 & & 0 & 12 \\
\hline
\end{tabular}

diperoleh hasil pada kombinasi kedua masalah transportasi tidak seimbang yaitu, $2 * 3+1 * 2+4 * 1+2 * 5+1 * 4+2 * 1=28$

Dari contoh kasus masalah transportasi seimbang, Kandidat- kandidat yang terpilih menghasilkan dua kombinasi. Kombinasi pertama masalah transportasi seimbang memiliki sel-sel yang teralokasi yaitu (S1,D2), (S2,D1), (S2,D4), (S3,D1), (S3,D2), (S3,D3) dengan solusi layak awal atau biaya transportasi sebesar \$23. Sedangkan kombinasi kedua masalah transportasi seimbang dengan sel-sel teralokasi yaitu (S1,D3), (S1,D4), (S2,D1), (S2,D4), (S3,D1), dan (S3,D2) dan menghasilkan solusi layak awal atau biaya transportasi sebesar \$28 (untuk perhitungan kombinasi kedua masalah transportasi seimbang dapat dilihat pada lampiran). Dengan membandingkan solusi layak awal masalah transportasi seimbang kedua kombinasi tersebut maka biaya transportasi distribusi akan minimum jika alokasi supply dan demand sesuai alokasi supply dan demand pada kombinasi pertama masalah transportasi seimbang diatas yaitu (S1,D2), (S2,D1), (S2,D4), (S3,D1), (S3,D2), (S3,D3) dengan solusi layak awal sebesar \$23.

\section{Kesimpulan}

Penggunaan BCM berdasarkan pada pemilihan kandidat terbaik serta solusi layak awal yang didapatkan berdasarkan pada

algoritma $\mathrm{BCM}$, di mana metode $\mathrm{BCM}$ akan menghasilkan kombinasi -kombinasi alokasi biaya transportasi. Kombinasi yang menghasilkan total biaya terkecil akan dipilih sebagai kombinasi terbaik. Pada contoh kasus yang dipaparkan terlihat bahwa $\$ 1005$ adalah ongkos minimum pada contoh kasus pertama, sedangkan \$23 adalah ongkos minimum yang diperoleh pada contoh kasus kedua.

\section{Daftar Pustaka}

[1] Taha, Hamdy A. 2007. Operations Research An Introduction. New Jersey: Pearson Prentice Hall.

[2] Tamin O. Z. 2000. Perencanaan dan Permodelan Transportasi. Bandung: Penerbit ITB.

[3] Dantzig, George B. dan Mukund N. Thapa.1997. Linear Programming 1:Introduction. Newyork: Springer.

[4] Siswanto. 2007. Operations Research. Jakarta : Erlangga.

[5] Hlayel, Ahmad A. 2012. The best candidates method for solving optimization problems. J. Comput. Sci.,

[6] 711-715. DOI: 10.3844/jcssp.2012.711.715. 